\title{
FLOWERS IN CLASSICAL MALAY LITERATURE: A STUDY OF AESTHETICS
}

\section{(Bunga dalam Kesusasteraan Melayu: Satu Kajian Estetika)}

\author{
Mohamed Nazreen Shahul Hamid* \\ mohamednazreen25@gmail.com
}

School of Languages, Civilisation and Philosophy, Universiti Utara Malaysia

Syahidatul Munirah Badrul Munir

syahidatul.nilakandi@gmail.com

School of the Arts, Universiti Sains Malaysia

Corresponding author (Pengarang koresponden): *

To cite this article (Rujukan artikel ini): Mohamed Nazreen Shahul Hamid \& Syahidatul Munirah Badrul Munir. (2021). Flowers in classical Malay literature: A study of aesthetics. Malay Literature, 34(1), 1-20. http://doi.org. 10.37052/ml34(1)no1

\begin{tabular}{|llllll|}
\hline $\begin{array}{l}\text { Received: } \\
\text { Peroleh: }\end{array}$ & $21 / 7 / 2020$ & $\begin{array}{l}\text { Revised: } \\
\text { Semakan }\end{array}$ & 14/9/2020 & $\begin{array}{l}\text { Accepted: 5/2/2021 } \\
\text { Terima: }\end{array}$ & $\begin{array}{l}\text { Published online: } \\
\text { Terbit dalam talian: }\end{array}$
\end{tabular}$\quad$ 3/6/2021

\begin{abstract}
Flowers are among God's amazing creations in the mortal world. There are a variety of flowers in the Malay world, such as the hibiscus, various types of jasmine and the lotus. These flowers are recorded in old Malay texts. Therefore, this paper examines flowers in traditional or classical Malay literature as elements employed, mentioned or used metaphorically for a specific purpose, which clearly shows the wisdom of the Malays of old. The methodology employed for this study was library research as well as textual analysis to analyse relevant data. A conceptual framework related to literary aesthetics was used as the basis of the study. The study finds that in Malay texts, flowers are used for both their figurative and literal meanings. This study is important in demonstrating the ingenuity of the Malays.
\end{abstract}

Keywords: flowers, aesthetics, symbolism, literal, ingenuity

(C) Dewan Bahasa dan Pustaka. 2021. This work is licensed under the term of the Creative Commons Attribution (CC BY) (http://creative commons.org/licenses/by/4.0/)

ISSN: 0128-1186 e-ISSN: 2682-8030 


\section{Abstrak}

Satu daripada ciptaan Tuhan yang menakjubkan di alam maya ini ialah bunga. Terdapat pelbagai bunga dalam dunia Melayu seperti bunga raya, melati, seroja dan melur. Banyak teks Melayu tradisional merakamkan perihal bunga-bunga ini. Artikel ini mengkaji bunga dalam sastera Melayu tradisional sebagai elemen yang digunakan, disebut atau diumpamakan dengan tujuan tertentu yang menampakkan kebijaksanaan orang Melayu sejak dahulu kala. Metodologi kajian ini menggunakan pendekatan kepustakaan dan analisis tekstual bagi menganalisis data yang berkaitan. Kerangka konseptual berkaitan dengan estetika sastera digunakan sebagai landasan kajian. Kajian mendapati bunga dalam teks Melayu tradisional disampaikan secara perlambangan dan literal oleh pengarangnya. Kepentingan kajian ini adalah untuk memperlihatkan kecerdikan akal budi bangsa Melayu.

Kata kunci: bunga, estetika, perlambangan, literal, kecerdikan

\section{INTRODUCTION}

In general, studies of old Malay literary texts have shown that they were created by people who were very much influenced by nature. This is because the lives of the Malays, especially in primitive times, depended greatly on nature. The Malays learned about nature and its varied behaviour. The ability to "read" nature allowed the Malays to recognize hospitable and inhospitable land for settlement. Rivers and the sea were studied as sources of food or income. All of this influenced the thoughts and feelings of the Malays. As a result, a kind of harmonic unity was established between the Malays and the flora and fauna in their everyday surroundings.

Flowers are a divine creation that make the world a nicer place. There are a variety of flowers that can be found in the Malay world, such as the hibiscus, jasmine and lotus. Many flowers are not only pretty but also produce a unique fragrance. A little more analysis reveals that the term "Melayu" (Malay) itself has its origin in the word "mala", meaning "flower" or "fragrance", because the Malays were closely associated with flowers. ${ }^{1}$ It is from flowers that the Malays derived all kinds of knowledge, which shows their ingenuity. Flowers were used in concoctions for personal and beauty care, in addition to medicinal and decorative purposes. Flowers feature in Malay mythology, where they take on sacral, mystic and noble elements, to the point that they are no longer confined to one locality but reach across a wider geographic area. 
All of the above are recorded in the old Malay texts. In connection with this, the present article will study flowers in traditional or classical Malay literature as elements employed or used metaphorically for certain reasons, thus clearly showing the wisdom of the Malays. This study was performed using library research as its methodology as well as textual analysis to obtain relevant data. The conceptual framework used was that of aesthetics in order to understand how flowers were used by the Malays to function as symbols and metaphors, as decorative elements and also in religious and cultural ceremonies. All of this will be discussed by applying certain flower elements from old Malay literary texts in order to showcase the ingenuity of the Malay mind.

\section{THE CONCEPTUAL FRAMEWORK OF AESTHETICS}

According to René Wellek (Hirsch, 1978: 97), the general public is incapable of valuing and appreciating a work of art without giving it certain elements, reminding that the evaluation and appreciation will not disregard the close connection between the work with cultural history and the place in which it was created. This is because the value elements used by the creator of the work differs according to the perspective and approach that he uses. It is through this difference of perspective that different methods and results are created. It is also here that the width and breadth of scope for analytical study and appreciation of art is located (Mana Sikana, 2013: 129).

Basically, aesthetics - the beauty of literature - is what makes reading material enjoyable and interesting. In fact, aesthetics has been accepted as literature's most important special characteristic (Watson, 1973: 43). Aesthetics is a splinter of the philosophical epistemology that states that aesthetics is an element delicately implied and expressed in texts, which brings joy when experienced through reading, listening or viewing (Fry, 2012: 95). Apart from this, aesthetics is closely connected to human emotions, such as feeling sad, happy, angry, noble or proud. Aesthetics also looks at ugly and disgusting elements as having a certain kind of beauty. In sum, the philosophy of aesthetics in literature discusses the values of beauty, rhetoric, narrative and authorship. In fact, Plato (Warry, 1964: 183) stressed that aesthetics has to fulfil a responsibility to the audience; it should exist within society and not merely for the sake of beauty.

From the theoretical angle, there exists the view that aesthetics can be found in all literary theories (Fry, 2012: 96). They merely differ in concept and in their principles of practice. With modern theories, aesthetics results 
from the combination of several literary approaches, either synchronically or consistently. By definition, aesthetic theory evaluates literary texts and the strengths of their figurative and literal meanings (Fry, 2012: 96). This definition comes close to that of Muhammad Haji Salleh (2002b: 34), which encompasses the aesthetics of poetic beauty as possessing a strong, solid and firm meaning presented in an explicit or implicit way. For prose, aesthetics should depict the experiences of real life with elements of seriousness, but open to elements of the magical, dramatic and episodic.

\section{TEXTUAL ANALYSIS}

Based on the conceptual framework above, in order to analyse the use of flowers in selected classical or traditional Malay texts, this article will divide the forms of use into two, namely literal and figurative uses. What is meant here by "figurative" use of flowers is that the author uses all kinds of flower elements as a medium to convey a certain meaning. "Literal" use means that flowers are mentioned in the text but are devoid of any hidden meanings.

\section{Figurative}

Flower elements used figuratively are a convention of the Malay literary tradition. According to Muhammad (2002a: 135), the symbolic use of elements of nature is what give Malay literature its unique identity. In fact, it is its most important tool. Muhammad also states that the Malays would "read" and interpret natural phenomena in order to understand an event or a future event. He further stresses that the Malays are patient and intelligent observers of nature. Nature is often seen as being able to sense human emotions and also being on their side to provide signs and reminders, or to celebrate (and mourn) an event or situation (Muhammad, 2002a: 135). Nature provides a glimpse of true reality and it is this that is frequently sought by writers to be transferred into their works.

In the context of this study, it is found that classical or traditional Malay texts often employ flowers as symbols of happiness or sadness. To this end, the hibiscus is most often the choice of writers. For example, in Hikayat Amir Hamzah, the pleasure of the minister upon seeing a heap of treasure is described using the image of a blooming hibiscus:

Menteri kepada tempat perbendaharaan itu. Apabila Alkis Menteri melihat harta perbendaharaan itu terlalu banyak, maka hatinya pun terlalu sukacita; mukanya berseri-seri seperti bunga raya kembang. Maka 
MOHAMED NAZREEN SHAHUL HAMID AND SYAHIDATUL MUNIRAH BADRUL MUNIR

ia pun berfikir di dalam hatinya, "Adapun harta ini terlalu banyak, jika aku ambil dengan setahu Khoja Bakhti Jamal ini, nescaya keluarlah rahsia ini. ..(Hikayat Amir Hamzah, 1987: 3)

[The minister was taken to the treasury. When Minister Alkis laid eyes on the great measure of treasure, his heart leapt up; his face blossomed like a hibiscus in full bloom. He thought in his heart, "Even though this treasure is plentiful, were I to take some with the knowledge of Khoja Bakhti Jamal, the secret would come out. .....]

The hibiscus blossom, with its bright red colour and large size, is a suitable symbol for the feeling of great pleasure here. In the context of the excerpt above, Minister Alkis' pleasure shows on his face the moment he lays eyes on the large amount of treasure, and his excitement is depicted by the author through the simile of the blooming hibiscus to show the character's fascination at the sight. In this instance, the hibiscus becomes a symbol that encompasses aesthetic value in order to portray the attitudes of a character who is dumbstruck by the sight of riches. According to Eizah (2019: 50), portrayals in literary works can be appreciated fully when the expression conveys an image, emotion and idea to the audience. Hence, the author has successfully conveyed all connotations of a symbol. Even so, the image of the hibiscus not only conveys awe and pleasure, but also depicts anger or displeasure in line with its bright shade of colour. This is also seen in Hikayat Amir Hamzah, in the episode where the king, Raja Khusyan Syah, experiences extreme displeasure when he hears of Amir Hamzah's great exploits:

... pergi ke negeri Zamin Tauran mendapatkan anaknya. Apabila Raja Khusyan Syah, raja negeri Kaldum Taurab itu mendengar sembah orang itu, maka ia pun marah, mukanya merah seperti bunga raya, serta berkata: "Lihatlah Hamzah Arab itu, menunjukkan laki-lakinya kepada aku maka ia lalu ikut pihaknegeriku ini. Arab itu belum merasai bekas tanganku ini. Baiklah, ... (Hikayat Amir Hamzah, 1987: 623)

[... went to the land of Zamin Tauran to fetch his child. When Raja Khusyan Syah, the king of Kaldum Taurab, heard the people's prayers, he was overcome with anger. His face became as red as a hibiscus, and he said, "Look at the Arab, Hamzah, flaunting his manliness in my face, passing through this, my land. The Arab has not yet felt my hand. Well then....] 
From the angle of aesthetics, symbolism or use of an image must fit the connotation of the contextual aspect. This follows on from the fact that every author translates and arranges a particular image to convey a situation according to his own tastes or writing style. In this example, comparison is made to the face of Raja Khusyan Syah; the hibiscus is no longer a shining object, but instead its bright colour becomes the main focus in order to portray the feeling of utmost anger. Therefore, several meanings can be associated with the hibiscus flower. This variety is in line with the contextual aesthetics mentioned by Mana Sikana (2013: 140), whereby the function of literature is that of social documentation and protest. The hibiscus, in this context, has a dual function: to convey varied feelings of pleasure and of anger. It is this variety of thought that is capable of expressing all kinds of situations through beautiful expressions. The same symbol of anger can be found in the text of Hikayat Bayan Budiman, when the wife of Khojah Maimun hears the parrot say that men have greater intelligence than women:

... kerana laki-laki itu terlebih akalnya daripada perempuan." Setelah isteri Khojah Maimun mendengar kata bayan, maka ia pun terlalu sangat marah akan bayan, mukanya seperti bunga raya mérah. Setelah bayan melihat isteri Khojah Maimun marah itu, maka bayan pun terlalu takut, kalau-kalau diperbuatnya seperti tiung itu. Maka kata bayan, "Pada bicara ... (Hikayat Bayan Budiman, 1966: 97)

[... because men have greater intelligence than women." Hearing these words spoken by the parrot, the wife of Khojah Maimun became greatly angered, and her face went as red as a hibiscus. Seeing this, the parrot became very afraid that he might meet the same fate as the mynah. Said the parrot, "In my view...]

The image of the hibiscus is also used in the episode involving Raja Kelana Hitam in Hikayat Merong Mahawangsa to signify anger when he is not appointed as king of Kedah:

... oleh Raja Benua Siam serta dengan suratnya bawa pergi ke Kedah menamakan raja Kedah itu." Demi didengar oleh Raja Kelana Hitam, maka naik marahlah ia, mukanya merah seperti bunga raya, serta titahnya, "Main yang mana kamu tewas dan peperangan yang mana kamu sudah alah, tiada patutkah aku menjadi raja di dalam negeri Kedah? Jika tiada boleh aku menjadi ... (Hikayat Merong Mahawangsa, 1998: 64) 
[... by the King of Siam, with his letter, to name the king of Kedah." Upon hearing this, Raja Kelana Hitam became enraged and his face went as red as a hibiscus, and he said, "Which battle have you seen, and which war have you fought—should not I be king, ruling the land of Kedah? If I cannot be .... ]

Scientific research has shown that the hibiscus originated in China, yet it grows abundantly in the Malay world (Ismail, 1977: 101). The beauty of this flower has made it well known and available in all countries. If it is not cut down, hibiscus bushes can reach a height of six metres. It has a smooth stem and several leaf shapes, depending on the type of hibiscus: oval, egg shaped and heart shaped (Ismail, 1977: 101). Its leaves are slightly serrated and moist. The flowers can be white, yellow, red, pink and purple. However, the type that is most well known in the Malay world is the red hibiscus.

The red hibiscus is most often associated with feelings of extreme pleasure or anger, as a person's face will turn red when experiencing these emotions. This is because whenever someone is very happy or very angry, the blood vessels in the face will dilate, resulting in an accumulation of blood that will make his face turn red (Styles, 2019: 15). Normally, a person who feels embarrassment will also experience this. These situations show how observant the Malays were concerning people's facial expressions. The change of facial expressions is then linked to elements of nature in the environment, here being flowers, to facilitate the conveying of a certain message.

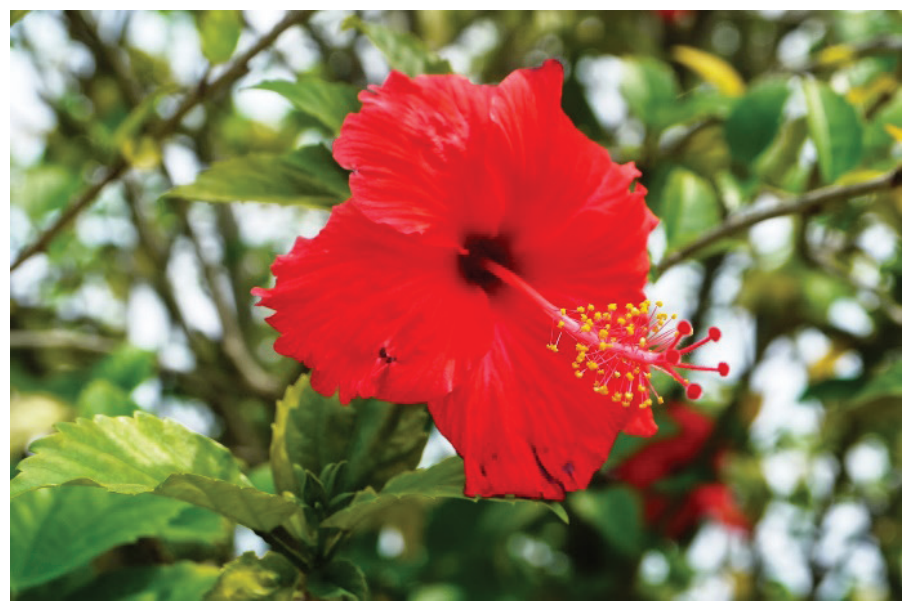

Figure 1 Red hibiscus. 
Next, in the Malay world, the symbolism of flowers and beetles is well known for depicting the relationship between men and women. On the whole, flowers are usually symbolic of women because the "soft" characteristics of flowers are attractive to beetles (which symbolize men) (Zurinah, 2010: 77). Therefore, in traditional Malay texts, it can be seen that flower elements are often used to portray the beauty and good character of women. For example, in Syair Ken Tambuhan, flowers are used as similes for the beauty of Raden Ratnajuita:

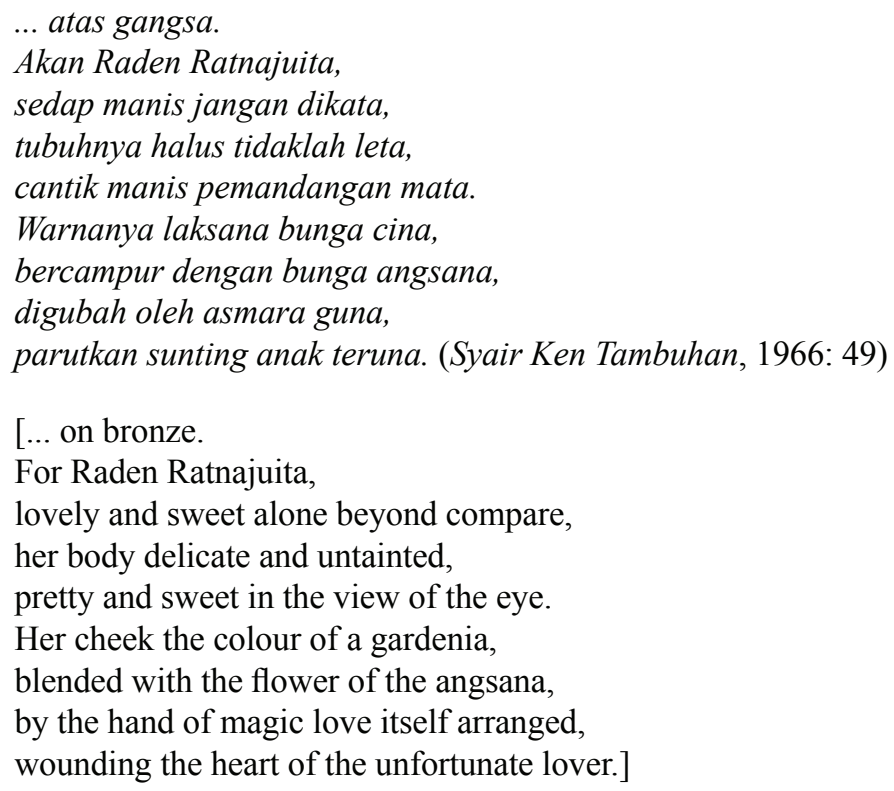

The angsana flower is that of a large wild plant that originated in South Asia but can also be found in Malaysia and the Philippines (Ismail, 1977: 187). The flowers emerge from between the leaves at the ends of branches and are a lovely yellow colour. This tree is taller than flowering trees usually are, and the flowers emerge once the tree has shed its leaves, exuding a strong fragrance. Therefore, comparing Raden Ratnajuita's beauty to the angsana flower is meant to convey that it is beyond compare, or at a high position, and outstanding, while the fragrance connotes Raden Ratnajuita's character, which is attractive in itself, apart from her physical beauty.

In Syair Siti Zubaidah, it is the champaca (bunga cempaka) that is used by the author as a comparison for the beauty of the princess called Puteri Jamjan, as can be seen in the following excerpt: 


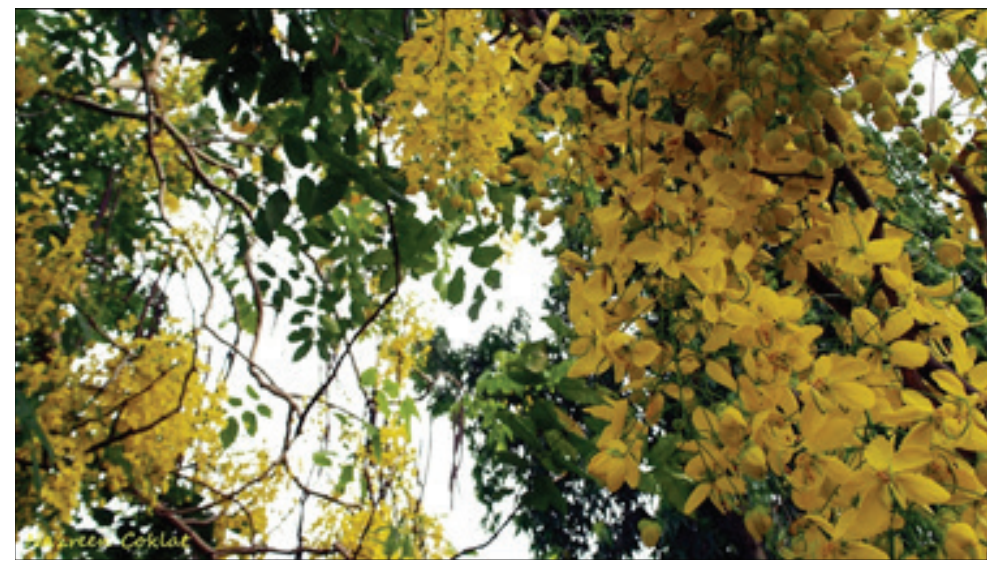

Figure 2 Angsana flowers.

Raja Parsi pulak menyambutnya, dikahwinkan pulak dengan puterinya, Puteri Jamjan iaitu namanya.

Itu pun baik parasnya juga, seperti Rukiah warnanya muka, laksana kuntum bunga cempaka, badannya langsar bagai dijangka.

Tujuh hari pulak lepasnya itu, Ahmad dikahwinkan dengan puteri itu, beristerilah pulak lagi suatu, jadilah empat isterinya. (Syair Siti Zubaidah, 1994: 547)

[The Persian king then him answered, and him then to his own princess wed, Puteri Jamjan her name was.

She was equally fair of face, her skin the colour of Rukiah's, alike the sweet-scented champaca's petals, her body well-shapen, slim and tall was.

Seven days later after this, after Ahmad was married to the princess, he took another wife to add to his, now altogether his wives numbered four.] 


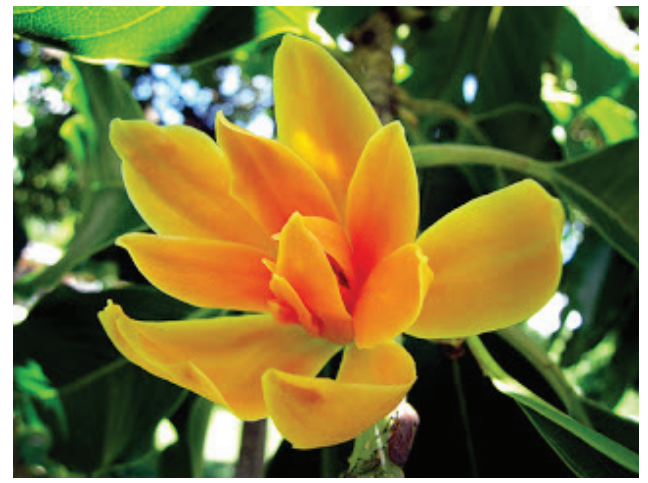

Figure 3 A yellow champaca.

The champaca (also called champak in English), whose scientific name is Michelia champaca, is a large, tall, green tree (Ismail, 1977: 176). Its flowers are yellow and well known for their scent. It is often planted as an ornamental plant. It is said to originate from India and Southeast Asia. Due to its look and characteristics, this flower, with its soft petals and strong scent, is often associated with women. Fragrant flowers often symbolize something beautiful and pure, and often become remembered or have their fame spread, as in the excerpt above. In both these texts-Syair Ken Tambuhan and Syair Siti Zubaidah - there is a similarity whereby the author chooses a yellow flower (yellow being the royal colour in Malay culture) to symbolize the beauty of a princess. Apart from this, both trees are big and tall. This is to ensure that these main characters in the respective works stand out more than the other women characters, apart from highlighting the high status of the princesses.

As mentioned earlier, flowers are also used to symbolically represent women's personalities. Flowers are soft and must be treated gently. Therefore, a woman's good character as a result of good upbringing are compared to flowers. In Syair Dang Sirat, for example, the daughter of the king of Pattani is described as being as good as a lotus flower in bloom:

Adat perintah tiada dicari

Menyanjung titah Raja Pisari

Berapa puluh anak raja-raja

Baik paras laku bersahaja

... sedang ...

Seperti bunga kembang seroja (Syair Dang Sirat: 34) 
[Not seeking decree nor ceremony

Always in full service to Raja Pisari

Howsoever many princesses

possessed of beauty and politeness

$\ldots$ are ...

alike fully-blossoming flowers of lotus]

According to Muhammad (2002b: 11), that which is beautiful can be in the form of words, plot or character. Muhammad's view is in line with that of Braginsky (1994: 46), whereby one of the points of excellence in literary works that can be considered as being of utmost importance is beauty (external beauty) reflected in the imagery and in the arrangement of words. The six lines of Syair Dang Sirat fulfil this aspect of aesthetics as outlined by both Muhammad and Braginsky, that is, the stanza is complete with a regular rhyme scheme and arrangement of words (external beauty), and it objectively depicts the character of the princess of the king of Pattani by making use of the lotus flower symbolism. Syair Dang Sirat can be seen as being compact in its aesthetics, which covers not only the beauty of its authorial structure but also its implied meaning. From the scientific point of view, the lotus is an aquatic plant that comes from India. Lotus plants are frequently seen on the surfaces of calm waters as its leaves float on the water. Its flowers are white or pink and has between 20 or more petals on each blossom (Ismail, 1977: 253). In line with the characteristics of this flower, the princesses of the king of Pattani are likened to these flowers,

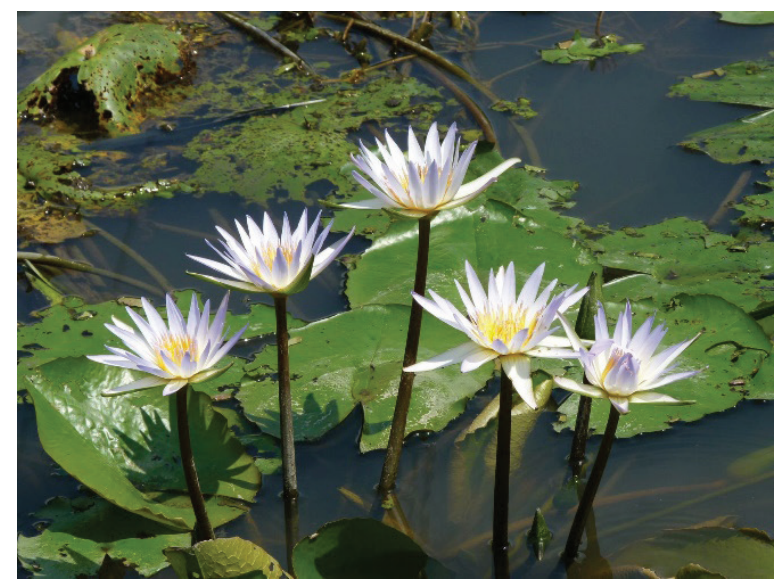

Figure 4 Lotus. 
which float serenely on water. It stays in the middle of ponds, set apart by its surroundings - water and the wide leaves of the lotus - which surround the flowers and thus shield and protect them.

Flowers are also used in texts to describe drunkenness. The flower that is used for this purpose is the basil flower, a herb whose flowers, leaves and seeds can be used. Each part of this plant has a particular smell and taste, which is sweet and fragrant, depending on its quality. However, there are certain types of basil that can cause intoxication when added to a drink (Ismail, 1977: 214). This fact is also found in classical Malay texts, in which drunkenness is often associated with the basil flower, when a character consumes drinks to which basil flowers are added. Such is the case in the text of Hikayat Bayan Budiman:

... kira-kira setempayan diminumnya. Maka ia pun mabuklah, seperti raksasa lakunya, gemuruh bunyi suaranya. Orang melihat dia ada yang takut, ada yang suka tertawa. Bermula, setelah bunga selasih mabuknya segala orang yang minum itu, maka berbunyilah segala bunyi-bunyian. Biduan yang baik suaranya itu pun bernyanyilah, berbagai-bagai ragam lagunya. Maka orang ... (Hikayat Bayan Budiman, 1996: 264)

[... he drank a whole potful. And thus he was drunk, and acted like a monster, with a voice like thunder. Some who saw him became afraid, some fell about with laughter. After all the people who had drunk of the basil flower were drunk, all kinds of sounds were heard. The singers with beautiful voices burst into all manner of song. Then the people ...]

Drunkenness due to intoxication caused by basil flowers is also mentioned in Hikayat Amir Hamzah, when Amir Hamzah meets Kulanggi:

... maka segala pahlawan itu pun masing-masing membawa asyiknya, dan yang menuang minuman itu pun merahlah matanya. Pada ketika itu, Amir Hamzah juga telah bunga selasih mabuknya, dan dalam khayal. Maka ia pun memandang kepada Kulanggi, seraya bertitah: "Hei saudaraku, pada sebelah negeri Rukham ini adakah negeri lagi?" Maka sembah ... (Hikayat Amir Hamzah, 1983: 678)

[... then all the warriors became intoxicated, and the people pouring the drinks became red-eyed. At this time, Amir Hamzah had become drunk from the basil flowers, and was in a stupor. And thus he looked at Kulanggi, and said: "Hey, my brother! Is there another land beside this land of Rukham?" Then answered...] 


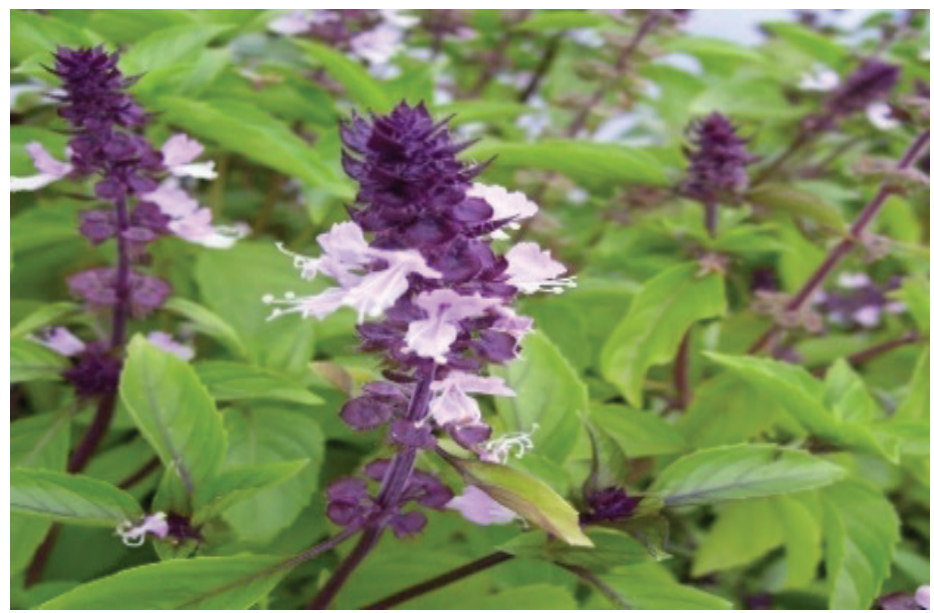

Figure 5 Basil flowers.

Based on these excerpts from Hikayat Bayan Budiman and Hikayat Amir Hamzah, it is clear that drunkenness is associated with the basil flower. In fact, this is no ordinary drunkenness but an intoxication that makes one unconscious of one's actions, as if in a trance. One aspect of aesthetics, according to Braginsky (1994: 25), is that the beautiful is something that is out of the ordinary, full of wonder (hairan), strange (ajaib), unusual (gharib) and full of spectacle (temasya). As mentioned earlier in the discussion about the concept of aesthetics, beauty or aesthetic quality does not lie in the meaning or plot of a beautiful story alone. Beautiful expressions are brought to the foreground, even when describing something impure. With reference to these two texts above that mention the basil flower, they show that it can bring about a negative outcome, and therefore these texts still adhere to Braginsky's idea of beauty, in that they highlight something unusual and full of spectacle (temasya). It is clear from these two excerpts that the characters presented are involved in a spectacle. Thus, it can be summarized that the author includes these events as a kind of social critique by depicting the unusual excesses of the characters because these are not in line with the cosmology of Malay custom, which is delicate and beautiful. Interestingly, the Malays' knowledge of the natural world - in this case, the intoxicating properties of the basil flower - are depicted imaginatively. Therefore, the situations depicted are extremely important as social documents that showcase the local genius of the Malays. 
Analysis of the figurative use of flowers shows that each of these flowers suits the meaning that is to be conveyed by the author. The author also uses the flower image to showcase his authorial style. This adds to the aesthetic value of the text concerned. Za'ba (1934: 14) has argued that using elements of nature figuratively would attract people and enrich the beauty of the language. This analysis also successfully reveals the genius of the authors of traditional or classical works using elements, in this case flowers, as symbols for certain issues or events in the work.

Apart from this, an analysis of the symbolism also shows that aesthetics is the basis for the excellence of the traditional works of literature. This is because aesthetics is that which brings out the beauty in such works, which attracts readers. Muhammad Haji Salleh (2002: 234) states that it is this beauty that is good for both the author and the readers. Beauty helps people feel good and become more humane. The readership of such works consists of people who love beauty. Therefore, it is not surprising that authors of traditional works use flower symbols in an effort to beautify their works and attract readers.

\section{Literal}

As mentioned earlier, apart from using flowers figuratively in classical or traditional Malay literary works, they are also used according to their denotative meaning or physical form.

The use of flowers in their physical form or literal sense is usually as adornments for women. For example, in Pelayaran Abdullah ke Kelantan, Abdullah Munsyi is amazed at the way the women of Kelantan adorn themselves, particularly their hair, using jasmine flowers:

... ia dekat2 perahu segala dagang berjalan berduyun2. Adapun pakaiannya itu berkemban sahaja dengan tiada berbaju dan rambutnya bersanggul lintang sangkut. Maka dipakainya bunga melur berumbai2, panjangnya sampai ke lututnya. Maka ada pula yang memakai bunga melur berkarang, dengan berbagai 2 jenis rupanya: ada yang seperti siku keluang dan ada berkerawang, terlalu indah perbuatannya; tiada pernah sahaya lihat dalam Melaka atau Singapura karangan bunga yang demikian itu bagusnya. Syahdan ada pula orang yang menjadi alku atau pinang muda yang datang kepada segala perahu2 dan bertanyakan perkara itu. (Pelayaran Abdullah ke Kelantan, 1838: 105) 
$[\ldots$ it is near where the crowd of foreign boats ply. The clothing they wear is nothing more than a sarong wrapped around the body at chest height, without a blouse. They wear their hair in a decorated bun, with jasmine flowers in strands so long that these reach down to their knees. Some wear jasmine in bunches of various arrangements: some in a zigzag pattern and some in a scroll pattern. Never in all of Malacca or Singapore have I seen flowers arranged in such an excellent manner. Then there are pimps or go-betweens that approach the many boats making enquiries about their matters.]

There is no figurative or symbolic element ascribed to the jasmine flower in this excerpt of Pelayaran Abdullah ke Kelantan. It is merely a record that depicts the situation at the time, with the writer's opinion added in, in line with the cosmology of the community's culture. However, Braginsky (1994: 8) stresses that outward beauty is also created by a well-structured text. In this case, contemporary records or literal statements also involve the aspect of aesthetics as these situations show the cultural landscape of the Malays, whereby natural images are a part of people's lives, and this is where the aesthetic value of Malay culture lies. Jasmine is a tropical flower that grows abundantly in India. In the Malay world, the majority of jasmine was brought in from India. Jasmine is a low shrub or climbing plant that is often planted in gardens and parks (Ismail, 1977: 132). This flower is often planted for its sweet scent and white blossoms. The flowers can be strung on a thread into garlands for self-adornment, as mentioned in the excerpt above, and can enhance the glow of a beautiful woman's countenance.

Apart from use as adornments, flowers were also used to decorate parks and gardens. According to Hasrina (2016: 8), in traditional Malay literature, gardens are an exclusive area that can only be owned by kings and royal families. Therefore, in Malay traditional texts, there exist a variety of names for gardens, according to their function. There were Taman Larangan, or Forbidden Gardens, that were exclusively the place where kings and their princes and princesses enjoyed leisure activities. An example is the garden called Taman Banjaran Sari, which frequently features in panji (noble warrior) stories (Hasrina, 2016: 8). Apart from this, hunting gardens are also mentioned in historical literature. These were specifically reserved for the king and the royal family to sport and hunt in. Some gardens were more spiritual in nature, an example being Taman Ghairah (Garden of Desire), which is mentioned in administrative texts and in some hikayat. This type of garden was the place where the king would meditate and bring himself closer to God. 
Even so, it should be borne in mind that each garden had particular landscape elements, according to its function. Flowering plants, for example, were used as decorative elements in Taman Larangan (Forbidden Gardens). Such a garden is described as follows in Hikayat Hang Tuah:

... Adapun bumi taman itu ditambaknya daripada tanah koi dan ditanam serba bagai jenis bunga-bungaan, air mawar merah dan air mawar ungu dan bunga air mawar putih, cempaka dan bunga kenanga dan bunga melur dan bunga pekan dan bunga kembang setahun dan bunga serangkini dan bunga delima danta dan bunga pancawarna dan bunga seri kayu gading dan bunga mutia ... (Hikayat Hang Tuah, 1975: 492)

[... The garden was filled with hard soil and planted with all kinds of flowers, red roses, purple roses, white roses, champaca, ylang ylang, jasmine, kiss-me-quicks, asters, serangkini, white pomegranate, hydrangeas, night-flowering jasmine, and rose grape ...]

The above excerpt clearly shows that Taman Larangan were planted with all kinds of flowers. Each of these is beautiful and has its own fragrance. One example is ylang ylang, an evergreen bush with pliable yet easily-snapped branches and smooth stems and yellow flowers. The flowers emerge from the branches and ends of branches and have a very strong scent (Ismail, 1977, p. 164). These were planted in Taman Larangan to scent the water used by the king, princes and princesses for bathing. In terms of aesthetics, according

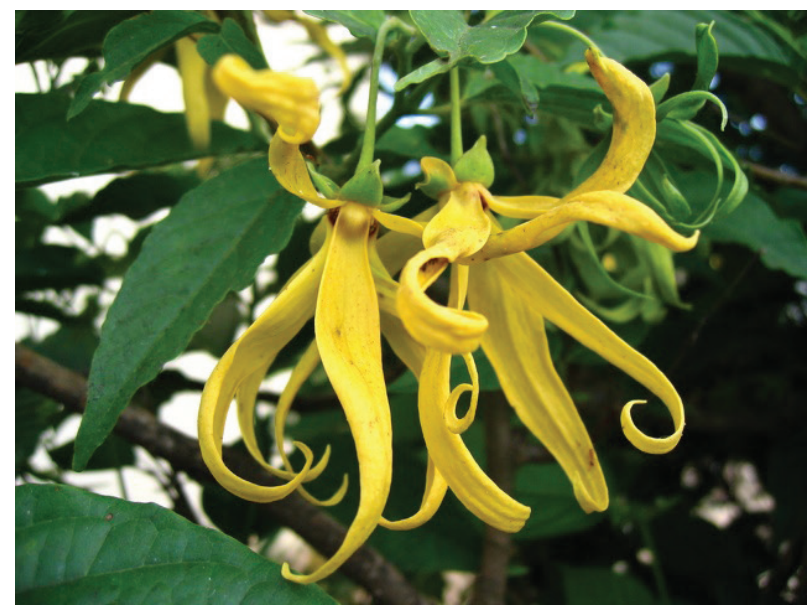

Figure 7 Ylang ylang. 
to Muhammad (2000: 234), whatever is beautiful must be sought because of its ability to bring pleasure; this will take an audience to a higher plane and to an extraordinary experience that may only exist in a literary heaven built by the imagination. It is clear that the depiction of Taman Larangan involves a descriptive technique through which the author tries to convey something that will not be seen by ordinary people, while at the same time documenting the royal customs in an imaginative manner so that ordinary people can appreciate such beauty.

Apart from functioning as decorations, flowers are also an important element in the religious and cultural practices of the Malays, a fact that is captured in Hikayat Bayan Budiman, where Sabariah is described visiting her late husband's grave:

Sabariah pun mengambil air sembahyang, lalu sembahyang asar. Maka ia pun minta doa akan suaminya. Setelah itu, maka ia menyapu kubur suaminya dengan rambutnya dan dibubuhnya bunga-bungaan. Apabila malam, ia tidur di kubur suaminya itu. Telah siang, maka keluar ia memungut bunga-bungaan itu dikarangnya, dan buah-buahan itu disuruhnya jual kepada ... (Hikayat Bayan Budiman, 1966: 297)

[Sabariah made ablution and prayed the afternoon prayer. She prayed for her husband. After this, she swept his grave with her hair and strewed it with flowers. When night came, she slept at her husband's grave. At daytime, she collected the flowers and arranged them, and then the ordered the selling .....]

This excerpt describes Sabariah cleaning her husband's grave and strewing flowers on it. According to Iman al-Subki, the strewing of flowers is considered neither haram (forbidden) nor makruh (discouraged) if done in moderation to sweeten the grave so that it is liked by the angels. ${ }^{2}$ Syeikh Sulaiman al-Jamal suggests that this can be a way of honouring the dead. ${ }^{3}$

Furthermore, the Malay kingdoms of the olden days were well known for their state-of-the-art ports at the time, as well as for their wealth of natural goods. All kinds of things were brought in from all continents, including flowers. In Hikayat Patani, for example, Ratu Kuning, who ruled Patani from about 1635 to 1686 , is shown by the author to have been self-sufficient by trading in produce from her gardens (Nik Anuar, 1999: 19):

... Raja Kuning kerajaan itu dipanggil orang Phra Cau pula dan Phra Cau itulah yang tiada santap hasil raja, dan yang jadi santapnya hasil 
tanaman pada kebunnya, daripada harga bunga dan harga sayur-sayuran itulah yang disantapnya dan dipakainya, dan sungguhpun demikian Phra Cau itu ada menaruh saudagar seorang Nakhoda Sandang namanya, dan Nakhoda Sandang ... (Hikayat Patani, 1992: 58)

[... Raja Kuning was given the title Phra Cau and it was this Phra Cau who did not take from the royal treasury, instead she would spend from what she obtained of her garden, from the price of its flowers and vegetables; the profit from this she would eat from and use. Even so, Phra Cau had an entrusted trader by the name of Nakhoda Sandang, and this Nakhoda Sandang ...]

Although Ratu Kuning lived a life of luxury as a royal princess of two kingdoms, Patani and Pahang, and later as ruler of Patani, she had an unusual personality as she did not like spending treasury money on her personal expenses, although permitted to do so. She enjoyed planting vegetables and flowers, and it was these that she would sell and use the profit of their sale to support herself. Braginsky (1994, p. 9) says that the beauty of thoughts, feelings and actions are not usually revealed to sight but visible to "insight" (sinar akal) and may raise readers' awareness about a person's image in all its spiritual perfection. This is, therefore, a depiction of a great ruler with a generous soul.

Based on an aesthetic analysis of what is literal, it can be seen that traditional Malay literature has the characteristics of didacticism. These didactic characteristics are evident in the benefits and usefulness highlighted in the texts. Muhammad Haji Salleh (2002a: 264) has said that Malay literature is the vessel for all things in the lives of the Malays. Its texts are veritable libraries of traditional knowledge, which includes knowledge about animals, clairvoyance, shamanism, language, agriculture and much more. Relevant to this study is the existing knowledge concerning the various uses of flowers that can be observed. The variety of knowledge displays the breadth and level of benefit that was obtained by the Malays. These literary works are sources of usefulness, beauty and elegance that radiate value and aesthetic quality.

\section{CONCLUSION}

To conclude, the Malays of old had a strong connection with the natural world. One of these elements is flowers, which are unique in form and fragrance. It is because of this close relationship that the authors of classic or traditional Malay texts often included flower elements in their works. The flower elements are both explicit and implied, thus proving the dynamics 
MOHAMED NAZREEN SHAHUL HAMID AND SYAHIDATUL MUNIRAH BADRUL MUNIR of the Malay authors of old in creating their literary works and adhering to wide-ranging aesthetic values.

Based on the analysis concerning the figurative and literal use of flower elements in classical or traditional Malay texts above, it is clear then that the flowers existing in the Malay world have their own function and meanings in the lives of the Malay people. Each natural characteristic of these flowers is explored in detail by the authors, then adapted to be applied in each text. Some aspects are retained to be used literally, while the meanings of others are expanded to be used figuratively. The ingenuity of the Malays is displayed in the use of the connotative and literal meanings of flowers. Aesthetics have been an integral part of the thought of Malay authors since the days of yore.

\section{NOTES}

1. Personal interview with Tenas Effendy at Universiti Sumatera Utara (University of North Sumatra) on 23 August 2013.

2. https://muftiwp.gov.my/artikel/al-kafi-li-al-fatawi/2784-al-kafi-908-hukum-menjualair-mawar-dan-bunga-segar-di-kuburan

3. https://muftiwp.gov.my/artikel/al-kafi-li-al-fatawi/2784-al-kafi-908-hukum-menjualair-mawar-dan-bunga-segar-di-kuburan

\section{REFERENCES}

A. Samad Ahmad, (Ed.). (1987). Hikayat Amir Hamzah. Dewan Bahasa dan Pustaka. Abdul Rahman al-Ahmadi, (Ed.). (1994). Syair Siti Zubaidah. Perpustakaan Negara Malaysia.

Abdullah Munsyi. (1983). Pelayaran Abdullah Ke Kelantan. Fajar Bakti.

Braginsky, V. I. (1994). Erti keindahan dan keindahan erti dalam kesusasteraan Melayu klasik. Dewan Bahasa dan Pustaka.

Eizah Mat Hussain. (2019). Simbol dan makna dalam pantun Melayu: Siri ilmiah APM-ITBM. Institut Terjemahan \& Buku Malaysia.

Fry, P. H. (2012). Theory of literature. Yale University Press.

Hasrina Baharum. (2016). Variasi landskap taman dalam karya Melayu tradisional. In Tunas Cipta, February, pp. 8-11.

Hikayat Patani. (1992). ). Studied and introduced by Siti Hawa Haji Salleh. Dewan Bahasa dan Pustaka.

Hikayat Merong Mahawangsa. (1998). Studied and introduced by Siti Hawa Haji

Salleh. Yayasan Karyawan and Penerbit Universiti Malaya.

Hirsch, E.D. (1978). Cultural literacy. Houghton Mifflin.

Ismail Saidin. (1977). Bunga-bungaan Malaysia. Dewan Bahasa dan Pustaka. Kassim Ahmad, (Ed.). (1975). Hikayat Hang Tuah. Dewan Bahasa dan Pustaka. 
MALAY LITERATURE VOLUME 34 NUMBER 1 JUNE 2021

Mana Sikana. (2013). Berdiri di akar diri. Kritikan sastera Melayu pascamoden. Institut Terjemahan \& Buku Malaysia.

Muhammad Haji Salleh. (2002a). Cermin diri, esei-esei kesusasteraan. Fajar Bakti.

Muhammad Haji Salleh. (2002b). Puitika sastera Melayu. Dewan Bahasa dan Pustaka.

Nik Anuar Nik Mahmud. (1999). Sejarah perjuangan Melayu Patani, 1785-1954. Penerbit Universiti Kebangsaan Malaysia.

Syair Dang Sirat. (n.d.). Microform. Malaysian National Library MKM 62. MS12381. BL-O MSS.

Styles, E. H. (2019). Human anatomy. Fine Line.

Teeuw, A., (Ed.). (1966). Syair Ken Tambuhan. Oxford University Press.

Warry, J. G. (1962). Aesthetic theory in Plato and Aristotle. Metheun.

Watson, George. (1973). The literature critics. The Wobern Press.

Winstedt, R. O. (Ed.). (1966). Hikayat Bayan Budiman. Oxford University Press. Za‘ba. (1965). Ilmu Mengarang Melayu. Dewan Bahasa dan Pustaka.

Zurinah Hassan. (2010). Unsur alam dalam puisi Melayu moden. Penerbit Universiti Kebangsaan Malaysia. 